Original Research Paper

\title{
Pemetaan Potensi Wisata Desa Gelanggang Kecamatan Sakra Timur Kabupaten Lombok Timur
}

\author{
Marham Jupri Hadi $^{1 *}$, Bukhari Muslim ${ }^{1}$, Meiyanti Widyaningrum ${ }^{1}$, Desi Suryati ${ }^{1}$, Muhammad Thohri ${ }^{2}$ \\ ${ }^{1}$ Universitas Nahdlatul Wathan Mataram \\ ${ }^{2}$ Universitas Islam Negeri Mataram
}

https://doi.org/10.29303/jpmpi.v3i2.1216

Sitasi: Hadi, M. J., Muslim, B., Widyaningrum, M., Suryati, D \& Tohri, M. (2021). Pemetaan Potensi Wisata Desa Gelanggang Kecamatan Sakra Timur Kabupaten Lombok Timur. Jurnal Pengabdian Magister Pendidikan IPA, 5(1)

Article history

Received: 20 November 2021 Revised: 30 Desember 2021

Accepted: 5 Januari 2022

*Corresponding Author:

Marham Jupri Hadi,

Universitas Nahdlatul Wathan

Mataram, Indonesia;

Email:

marhamhadi@gmail.com

\begin{abstract}
Pandemi Covid 19 memberikan dampak yang sangat memprihatinkan bagi seluruh masyarakat Indonesia terutama dalam bidang perekonomian. Salah satu upaya untuk bangkit dan memperbaiki kondisi tersebut adalah melalui pengembangan sektor pariwisata. Kegiatan pemetaan ini dilaksanakan oleh tim kuliah kerja nyata $(\mathrm{KKN})$ Tematik Universitas Nahdlatul Wathan Mataram bekerjasama dengan Pokdarwis Desa Gelanggang selama 45 lima hari. Berdasarkan hasil pemetaan potensi wisata tersebut, ditemukan beberapa lokus wisata yang bisa dikembangkan menjadi destinasi wisata pedesaan yakni Sungai Gelanggang dan Sawah, Situs Bersejarah Sombe, Kelompok Seni, serta Pusat Pelatihan dan Pemberdayaan Masyarakat.
\end{abstract}

Keywords: Pemanfaatan lahan; Budidaya; Lebah Klanceng.

\section{Pendahuluan}

Pandemi Covid 19 memberikan dampak yang sangat memprihatinkan bagi seluruh masyarakat Indonesia terutama dalam bidang perekonomian. Banyak perusahaan perusahaan terpaksa melakukan pemutusan hubungan kerja dengan karyawannya karena ketidakmampuan untuk membayarkan gaji mereka. Begitupun pada sektor pariwisata dimana pelarangan travel keluar negeri berdampak pada terjadinya penurunan yang sangat dramatis terhadap jumlah kunjungan ke Indonesia. Situasi tersebut diperburuk dengan adanya peraturan tentang pelarangan yang membatasi pergerakan masyarakat.

Kita telah memasuki tahun kedua dibawah kungkungan pandemic covid 2019. Kondisi yang sangat memprihatinkan ini menuntut kita untuk bisa survive (bertahan hidup). Dari sisi pemerintah upaya untuk mencegah penyebarannya telah dilakukan secara massif baik melalui kebijakan PPKM ataupun vaksinasi meskipun banyak menuai kritik dari berbagai pihak. Sedangakn dari sisi masyarakat, pandemi ini menjadi pemicu untuk berpikir lebih produktif, kreatif, dan inovatif dan salah satunya adalah dengan mengoptimalkan potensi-potensi yang ada di desa Gelanggang.

Salah satu upaya konkrit untuk merespon situasi tersebut adalah dengan melakukan kolaborasi antara akademi dan masyarakat dalam bentuk kegiatan pengabdian kepada masyarakat (Abdimas). Kegiatan Abdimas ini bertujuan untuk membantu pihak desa Gelanggang khususnya Pemerintah Desa dan Kolompok Sadar Wisata yang telah terbentuk disana untuk memetakan potensi wisata yang bisa dikembangkan di desa Gelanggang kecamatan Sakra Timur.

\section{Metode}

Kegiatan pengabdian ini diawali dengan melakukan observasi awal untuk mendapatkan gambaran umum tentang kehidupan masyarakat (agama, adat istiadat, serta rutinitas penduduk) yang ada di desa Gelanggang. Selain observasi, tim Abdimas UNW Mataram juga melakukan 
kunjungan-kunjungan dan diskusi dengan tokoh masyarakat serta dengan masyarakat biasa untuk mengidentifikasi permasalahan yang dihadapi oleh masyarakat desa. Dari hasil observasi dan diskusi tersebut, beberapa permasalahan yang perlu dicarikan alternatif pemecahan melalui kegiatan pengabdian masyarakat.
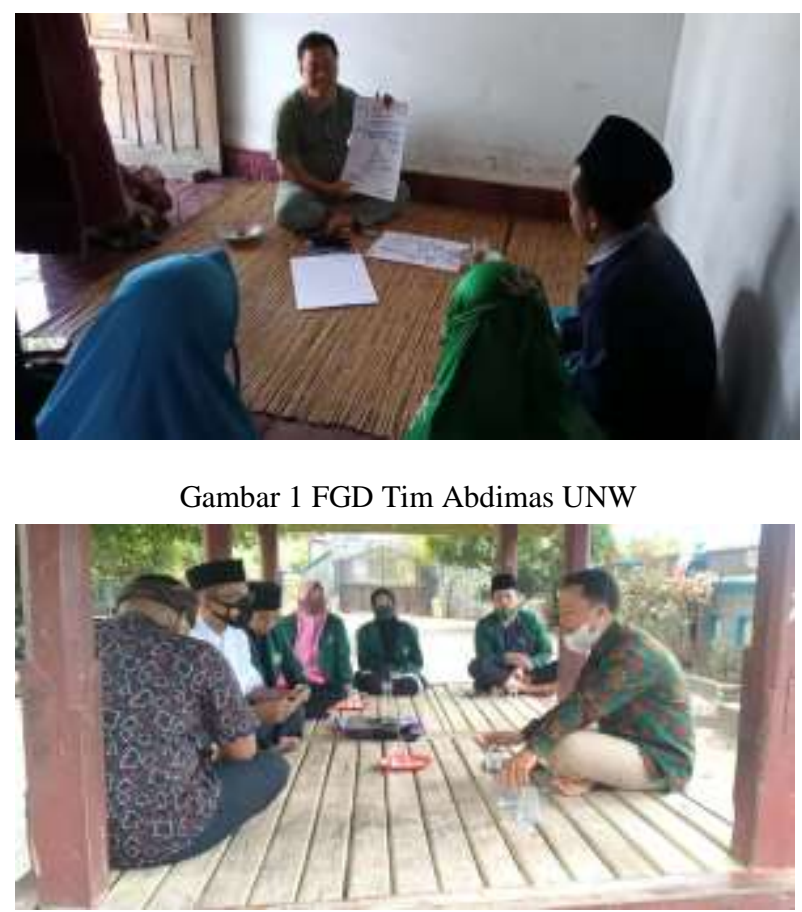

Gambar 2 Diskusi Awal Dengan Pemdes Gelanggang

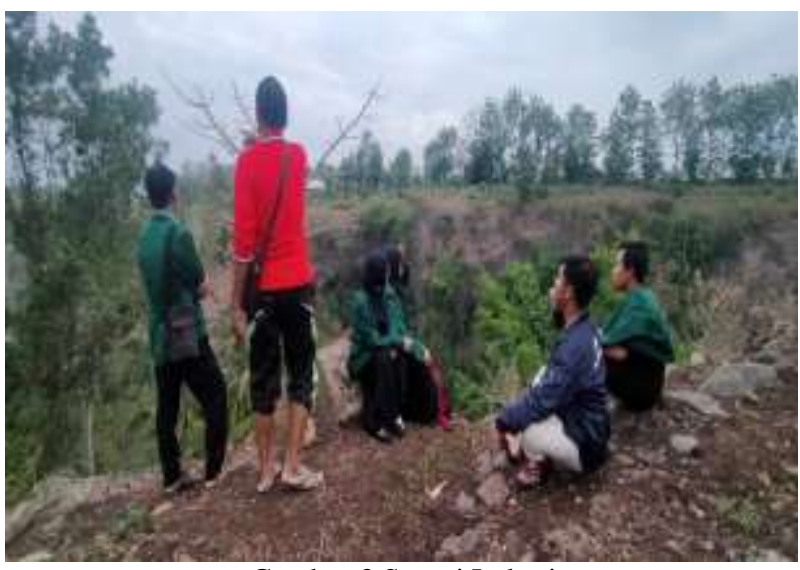

Gambar 3 Survei Lokasi

\section{Hasil dan Pembahasan}

Setelah melakukan kegiatan diskusi, observasi dan pemetaaan bersama dengan Pemerintah Desa Gelanggang dan Kelompok Sadar Wisata yang ada, terdapat beberapa potensi yang dimiliki oleh desa Gelanggang yang bisa menjadi modal pengembangan destinasi wisata pedesaan. Potensipotensi tersebut dikelompokkkan menjadi potensi Sumber Daya Manusia, Sumber Daya Alam Beserta Seni, Budaya, dan Sejarah. Secara lebih detail, potensi-potensi tersebut adalah sebagai berikut.

\section{Potensi Sumber Daya Alam}

Secara geografis, Desa Gelanggang berada di Kecamatan Sakra Timur yang berlokasi sangat dekat dengan beberapa destinasi wisata bahari yakni Pantai Labuhan Haji, Pantai Kuangwai, serta sentra penjualan ikan laut yakni Pelabuhan Tanjung Luar. Hal ini memungkinkan bagi para wisatawan untuk mendapatkan paket wisata yang lengkap (pantai, kuliner, dan sport). Selain itu, dari ujung utara sampai selatan Desa Gelanggang, yang berbatasan dengan Desa Menceh, terdapat sungai (Kokoh dalam bahasa Sasak) dengan kedalam kurang lebih 50 sampai 100 meter. Sungai tersebut memiliki maknet tersebut bagi para pencinta sport tourism, camping atau fishing.

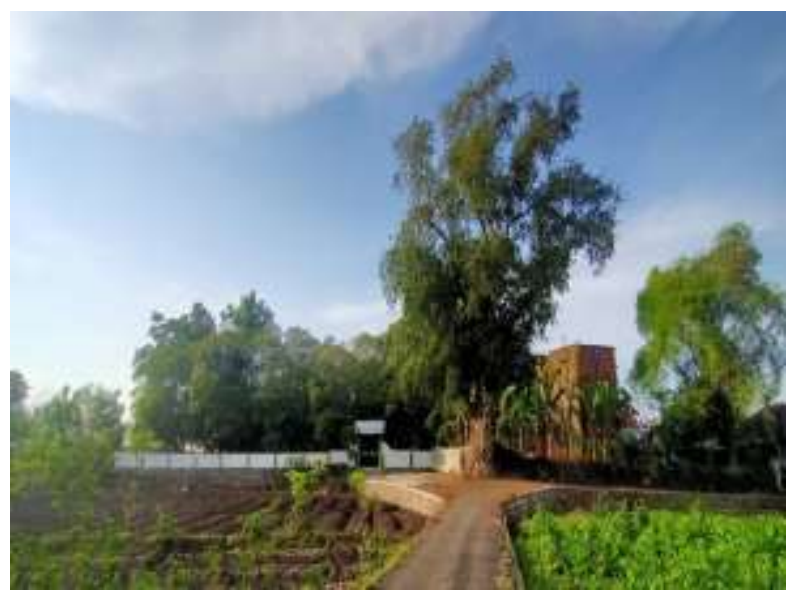

Gambar 1 Green view di Desa Gelanggangan

Desa Gelanggang juga dikenal sebagai produsen tembakau kelas dunia dimana pada musim panas kita bisa menyaksikan pemandangan hijau menguning sepanjang jalan utama desa. Kitapun bisa menyaksikan rutinitas masyarakat yang bergelut dengan tanaman tembakau baik dari proses pra penanaman sampai paska panen. Pemandangan ini akan menjadi daya tarik tersendiri bagi pengunjung yang tidak pernah melihat bagaiaman proses penanaman dan pengepakan tembakau sebelum diproduksi menjadi rokok. Pengunjung juga memiliki kesempatan untuk belajar dan 
berinteraksi langsung dengan masyarakat petani dan buruh tani tembakau. Adapun potensi pengembangan potensi sumber daya alam desa Gelanggang bisa berbentuk jogging track persawahan, susur sungai ataupun camping site.

\section{Potensi Sejarah, Seni dan Budaya}

Potensi sejarah Desa Gelanggang telah lama diceritakan turun temurun oleh para leluhur kepada anak cucu mereka. Tetapi potensi tersebut lambat laun bisa berubah menjadi sekedar cerita bahkan legenda yang bisa jadi diragukan kebenarannya oleh para generasi muda Desa Gelanggang karena sedikitnya upaya untuk mendokumentasikan, memelihara dan mempublikasikan bukti-bukti sejarah tersebut. Kegiatan Abdimas ini berpotensi untuk menginisiasi upaya pemeliharan sejarah yang ada di Desa Gelanggang.

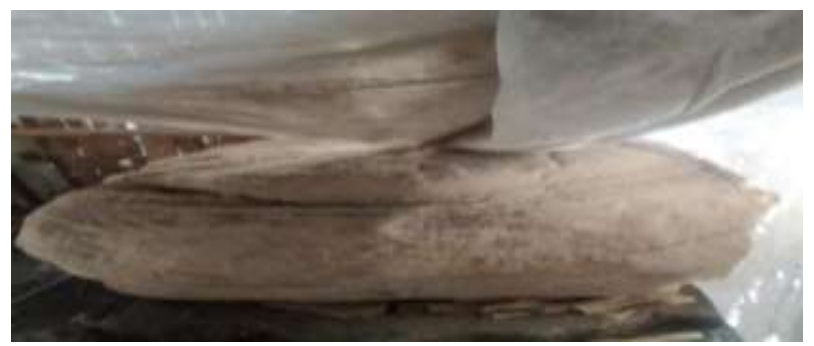

Gambar 2 Batu Tempat Mengikat Kuda Datu

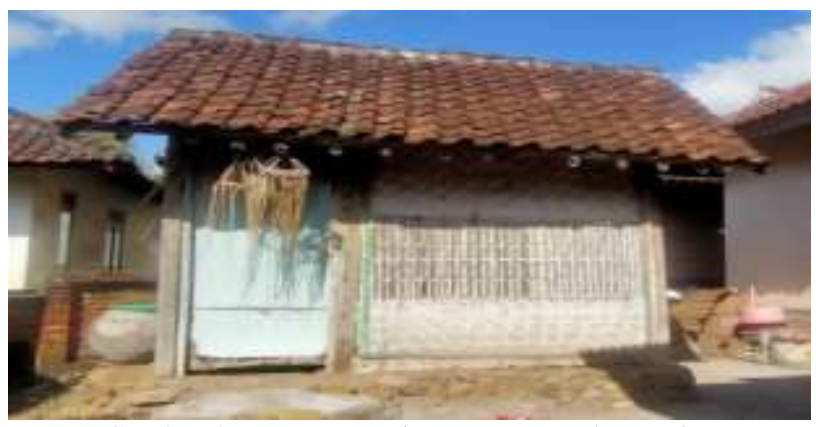

Gambar 3 Tempat Penyimpanan Batu dan Prako

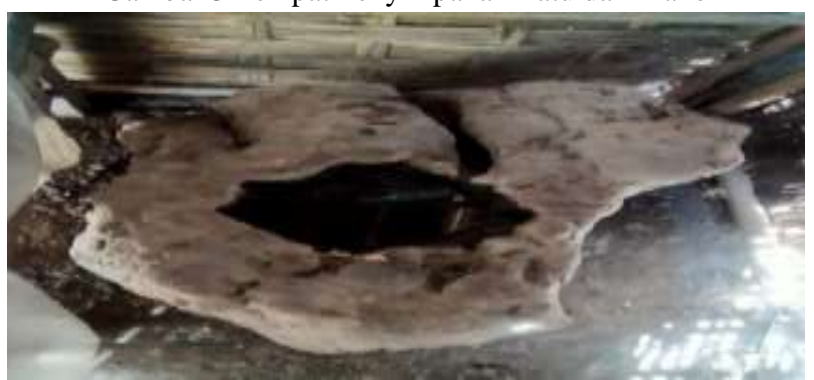

Gambar 5 Prako/ Tempat Minum Kuda Datu
Berdasarkan hasil obervasi dan diskusi dengan para tokoh yang ada di Desa Gelanggang, kami mengidentifikasi beberapa situs bersejarah yang bisa menjadi destinasi wisata yakni Sombe dan Gelanggang Bowoh. Kedua situs tersebut terkoneksi dengan sejarah Lombok, terutama dimasa perjuangan melawan penjajahan Kerajaan Karang Asem di Pulau Lombok. Berdasarkan penuturan tokoh yang ada di lokasi tersebut, Sombe merupakan pusat untuk melakukan kajian keislaman serta pengaturan strategi untuk melawan Kerajaan Karang Asem. Sedangkan Gelanggang Bowoh merupakan tempat penyimpanan warisan Datu (Raja) Sakra berupa tempat minum kuda Datu dan Batu Tempat mengikat Kuda Datu.

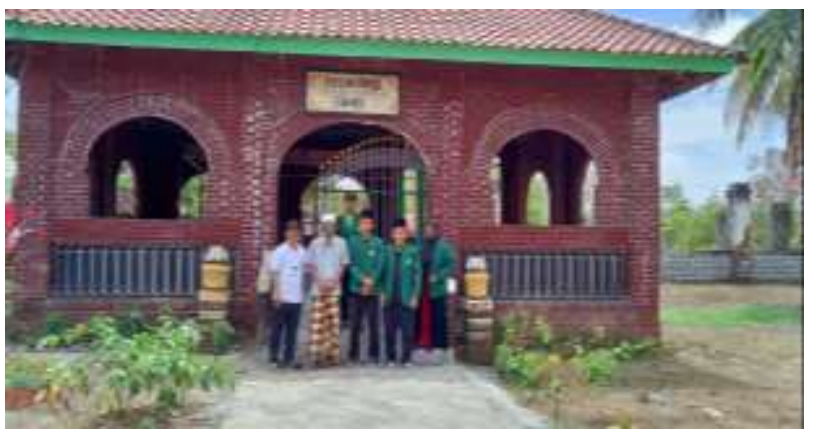

Gambar 6 Lokus Sejarah Sombe

\section{Kearifan Lokal Desa Gelanggang}

Salah satu elemen Budaya yang kental di Pulau Lombok terutama di Desa Gelanggang adalah potensi kearifan lokal yang diwariskan oleh para leluhur dan masih terpelihara sampai saat ini. Kearifan lokal atau local genuine merupakan hasil refleksi para leluhur yang didasarkan pada petunjuk kehidupan serta pengalaman penempaan diri untuk menjadi manusia sejati. Petunjuk kehidupan yang dimaksud adalah hasil tafsiran mereka tentang kitab suci Alqur'an serta nasehat-nasehat dari para tetua di Bumi Selaparang Lombok. Jadi, kearifan lokal bukanlah tidak bisa dipersepsi hanya sebagai warisan kuno (terbelakang) tetapi menjadi modal untuk untuk mempertahankan budi pekerti dalam era yang penuh dengan perilaku tidak manusiawi. Artinya, kearifan lokal yang ada, khususnya di Desa Gelanggang, perlu dikaji dan dijadikan referensi kehidupan bagi penerus generasi untuk mempertahankan identitas sebagai insan yang berbakti.

Berdasarkan hasil pengamatan dan diskusi dengan para tetua yang ada di desa Gelanggang, 
terdapat beberapa contoh kearifan lokal yang masih terpelihara dengan kuat di masyarakat desa Gelanggang. Misalnya, para tetua selalu berpesan untuk menjadikan hinaan/ celaan orang lain sebagai sabun (pembersih diri). Hal ini sangat relefan dengan ajaran Islam yang menekankan pentingnya bersabar dan bersyukur sebagai wahana peningkatan derajat keimanan seseorang. Contoh lainnya adalah ada pesan dari leluhur di desa Gelanggang untuk tidak membalas (balas dendam) atas perlakuan tidak baik orang lain. Kearifan lokal seperti ini mengajarkan agar seseorang tidak memelihara sifat dendam pada siapapu karena sifat ini akan merusak keharmonisan dalam kehidupan bermasyarakat.

Terdapat masih banyak contoh kekayaan spiritual (kearifan lokal) yang masih dipegang teguh oleh pelingsir (tetua) yang ada di Desa Gelanggang yang bisa menjadi magnet yang istimewa bagi wisatawan yang tertarik melakukan wisata pendidikan (Edutourism). Dengan meluangkan waktu yang cukup, para wisatawan bisa berinteraksi dan menggali nilai-nilai luhur yang dipraktikkan oleh para leluhur suku Sasak yang mendiami desa ini. Tentunya, interaksi yang inten akan memberikan dampak psikis kepada para wisatawan dalam bentuk ketenangan batin setelah mereka kembali dari kegiatan wisata di daerah pedesaan.

\section{Bubus Gelanggang}

Di setiap desa di Pulau Lombok kita akan mendengar nama Beliyan (tabib) baik yang kaitannya dengan masalah kelahiran maupun penyakit non medis. Pun di Desa Gelanggang, kita juga akan menemukan banyak beliyan (Tabib) yang para pasiennya berasal dari berbagai daerah di Pulau Lombok. Dalam tradisi pengobatan, khususnya di Desa Gelanggang, kita akan mendengar istilah Bubus Gelanggang. Bubus merupakan salah satu metode dan media dalam pengobatan berbagai jenis penyakit. Seringkali masyarakat yang datang berobat ke Gelanggang dengan menggunakan Media Bubus Gelanggang biasanya memiliki hubungan kekeluargaan dengan warga Gelanggang.

\section{Pengobatan Tradisional Gelanggang}

Salah satu warisan leluhur Desa Gelanggang adalah pengobatan Tradisional yang merupakan perpaduan antara pendekatan ilahiah dan alamiah, yang dipraktikkan oleh Beliyan atau Tabib. Pengobatan Tradisional yang masih bertahan sampai saat ini menjadi rujukan utama bagi masyarakat Gelanggang Buwuh, tanpa mengenyampingkan pengobatan medis (ilmiah). Bagi masyarakat Gelanggang Buwuh, setiap ada penyakit maka mereka akan mendahulukan pengobatan tradisional baru kemudian dilanjutkan dengan pengobatan medis. Ungkapan yang umum kita dengar yakni "Sasak Bejuluk" (utamakan pengobatan Leluhur). Pilihan tersebut sangatlah beralasan karena metode pengobatan Sasak berkembang ratusan bahkan ribuan tahun sebelum pengobatan medis datang ke Pulau Lombok.

\section{Potensi Sumber Daya Manusia}

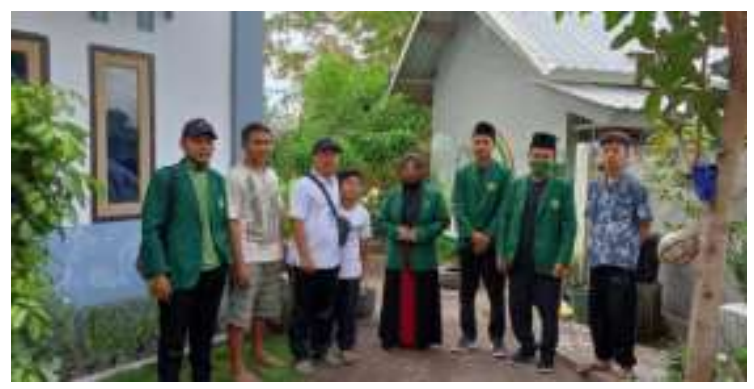

Gambar 7 Komunitas Rumah Pintar

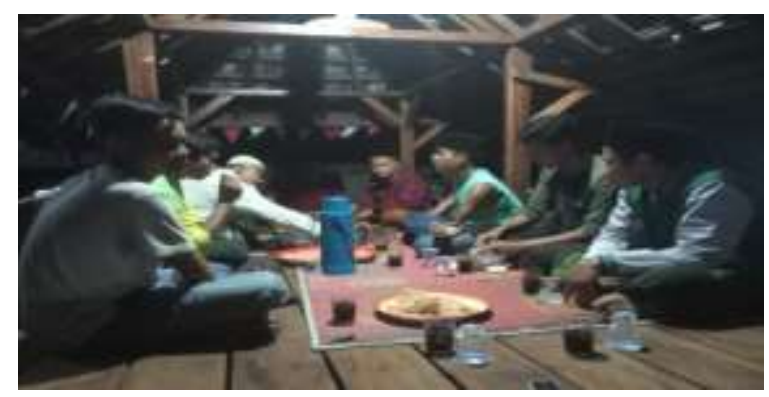

Gambar 8 Komunitas Pemerhati Wisata

Salah satu aspek penting dalam pengembangan potensi wisata pedesaan adalah adalah sumber daya manusia yang memiliki kepedulian dan kompetensi untuk untuk itu. Pada saat ini, desa Gelanggang telah memiliki komunitas yang memiliki kesadaran akan potensi wisata yand ada di desa tersebut. Komunitas ini terdiri dari berbagai kalangan masyarakat terutama pemuda, staff desa dan akademisi. Meskipun belum mendapatkan legalitas formal dari pemerintah kabupaten Lombok Timur dalam bentuk SK Pokdarwis, antusiasme komunitas pemerhati wisata pedesaan ini begitu besar. Ini 
menunjukkan bahwa potensi SDM yang ada menjadi embrio untuk pengembangan potensi wisata yang ada di desa Gelanggang menjadi destinasi wisata. Sentuhan lebih lanjut dalam bentuk pendampingan dan dukungan legalitas menjadi bagian yang perlu mendapat perhatian dari otoritas pemerintah daerah kabupaten Lombok Timur.

\section{Potensi Pengembangan Desa Gelanggang Sebagai Destinasi Wisata Pendidikan}

Dengan memperhatikan berbagai potensi wisata yang ada di Desa Gelanggang, kita bisa menawarkan satu ide untuk mengembangkan desa Gelanggang menjadi destinasi wisata pendidikan berbasis budaya dan alam (cultural and natural based education tourism). Wisata pendidikan atau education tourism merupakan kegiatan berwisata dengan tujuan utama untuk melakukan proses pembelajaran yang dilakukan minimal 24 jam dan kurang dari satu tahun. Praktik wisata pendidikan ini telah dilakukan di banyak tempat di Indonesia misalnya di Kampung Inggris, Kediri. Dalam konteks Lombok, kegiatan belajar sambil berwisata sedang dilakukan oleh Desa Tete Batu dengan mengusung konsep Kampung Inggris serta Wisata Pendidikan ala Beruga' Alam Institute (Hadi, Permata, \& Tarmizi, 2019). Keunggulan dari implementasi wisata pendidikan pada satu destinasi wisata adalah pengembangan kepribadian para pembelajar (wisatawan) dan masyarakat di destinasi wisata secara menyeluruh (Sharma, 2015)

\section{Kesimpulan}

Berdasarkan hasil kajian yang dilakukan oleh tim pengabdian masyarakat UNW Mataram, kami telah mengidentifikasi beberapa potensi yang bisa menjadi atraksi wisata. Potensi tersebut meliputi potensi sumber daya alam dalam bentuk lanskap persawahan dan aliran sungai besar, potensi sejarah, seni dan budaya serta potensi sumber daya manusia. Dalam rangka pengembangan potensi tersebut, Desa Gelanggang bisa dikembangkan menjadi destinasi wisata pendidikan. Hal ini bertujuan untuk memberikan dampak yang lebih besar kepada para wisatawan serta masyarakat desa gelanggang secara menyeluruh.

\section{Daftar Pustaka}

Hadi, ...., Permata, ...., \& Tarmizi, .... (2019). THE PRACTICE OF EDUCATION TOURISM: A CASE OF BERUGA' ALAM INSTITUTE. International Journal Of Applied Sciences In Tourism And Events, 3(2), 210-220. doi:10.31940/ijaste.v3i2.1492

Sharma, A. (2015) Educational Tourism: Strategy for Sustainable Tourism Development with reference of Hadauti and Shekhawati Regions of Rajasthan ,India. Journal of Knowledge Management, Economics and Information Technology. Vol.5, Issue 4 September 2015. Pp.1-17

Parwata, I. W., Antarini, L., \& Astara, W. (2021). Re-Desain Edu-Tourism "Kampung Petualang" di Desa Singapadu Tengah, Kabupaten Gianyar, Bali. Engagement: Jurnal Pengabdian Kepada Masyarakat, 5(1), 161-181. https://doi.org/10.29062/engagement.v5i1.7 $\underline{01}$ 